\title{
Microbial transformations of uranium in wastes and implication on its mobility
}

\author{
Arokiasamy J. Francis \\ Presented at the International Conference on Uranium Mining and Hydrogeology UMH V \\ TU Bergakademie, Freiberg, Germany
}

September 14-18, 2008

\author{
Environmental Sciences Department \\ Environmental Research \& Technology Division \\ Brookhaven National Laboratory \\ P.O. Box 5000 \\ Upton, NY 11973-5000 \\ www.bnl.gov
}

\begin{abstract}
Notice: This manuscript has been authored by employees of Brookhaven Science Associates, LLC under Contract No. DE-AC02-98CH10886 with the U.S. Department of Energy. The publisher by accepting the manuscript for publication acknowledges that the United States Government retains a non-exclusive, paid-up, irrevocable, worldwide license to publish or reproduce the published form of this manuscript, or allow others to do so, for United States Government purposes.




\title{
Microbial transformations of uranium in wastes and implication on its mobility
}

\author{
Arokiasamy J. Francis \\ Environmental Sciences Department, Brookhaven National Laboratory, Upton, \\ New York 11973 USA
}

\begin{abstract}
Uranium exists in several chemical forms in mining and mill tailings and in nuclear and weapons production wastes. Under appropriate conditions, microorganisms can affect the stability and mobility of $U$ in wastes by altering the chemical speciation, solubility and sorption properties and thus could increase or decrease the concentrations of $U$ in solution and the bioavailability. Dissolution or immobilization of $U$ is brought about by direct enzymatic action or indirect nonenzymatic action of microorganisms. Although the physical, chemical, and geochemical processes affecting dissolution, precipitation, and mobilization of $U$ have been extensively investigated, we have only limited information on the mechanisms of microbial transformations of various chemical forms of $U$ in the presence of electron donors and acceptors.
\end{abstract}

\section{Uranium in wastes}

Uranium in wastes is present in various chemical forms and may eventually exist in the environment as elemental, oxide, coprecipitates, ionic, inorganic-, and organic-complexes, and naturally occurring minerals depending on the process and waste stream. Uranium in ores is present as uraninite and pitchblende and in secondary mineral phases associated with silicates, phosphates, carbonates, and vanadates (Katz et al., 1986). The concentration of uranium can vary between 0.5 and 20\%, with the highest amount occurring in Canadian ores. Mill tailings, a byproduct of the mineral extraction process, contain up to $2 \%$ uranium. The treatment process residues contain sulfates, ammonia, tertiary amines, and organic solvents (Metzler 2004). Carbonate leaching has been used for in situ extraction of uranium. The residual uranium that has not been extracted may be present as a result of newly formed insoluble mineral phases (e.g. $\mathrm{CaSO}_{4}, \mathrm{MgCO}_{3}, \mathrm{Fe}(\mathrm{OH})_{3}$ ) 
which provide surface sites for uranium adsorption (Bostick et al., 2002). Uranium in the environment exists predominantly as $\mathrm{U}(\mathrm{VI})$ and $\mathrm{U}(\mathrm{IV})$ oxidation states while the former is more soluble and the latter quite insoluble and mobile.

\section{Biotransformation of Uranium}

Microbial activity could affect the chemical nature of $U$ by altering the speciation, solubility and sorption properties and thus could increase or decrease the concentration in solution and their bioavailability. Under appropriate conditions, dissolution or immobilization of $U$ is brought about by direct enzymatic or indirect nonenzymatic actions of microorganisms. These include (i) oxidation-reduction reactions, (ii) changes in $\mathrm{pH}$ and $\mathrm{Eh}$, (iii) chelation or production of specific sequestering agents, (iv) bioaccumulation by biomass, (v) biocolloid formation, (vi) bioprecipitation, and (vi) biotransformation of radionuclide-organic and -inorganic complexes (Francis, 1990). Both aerobic and anaerobic microorganisms are involved in the mobilization and immobilization of various chemical forms of $U$.

\section{Dissolution of Uranium}

Dissolution of uranium in ores by autotrophic sulfur- and iron-oxidizing bacteria is due to production of sulfuric acid and by heterotorphic bacteria and by fungi due to production of organic acids and chelating agents has been well documented in the literature (Francis 1990).

Autotrophic microbial activity. The chemical and biochemical mechanisms involved in microbial leaching or biomining of metals have been extensively studied and are used commercially for extracting copper and uranium from ores. The iron and sulfur oxidizing bacteria play a significant role in the solubilization of uranium from ores and in mill tailings. The role of autotrophic bacteria Thiobacillus ferrooxidans in the extraction of uranium from ore is due to indirect and direct actions. The indirect mechanism is confined to its generating the oxidizing agent, ferric sulfate, and the solvent sulfuric acid and to the involvement of $\mathrm{Fe}^{2+} / \mathrm{Fe}^{3+}$ in cyclically mediating the oxidation of insoluble uranium oxide to soluble uranyl ion $\mathrm{UO}_{2}+\mathrm{Fe}^{3+} \rightarrow \mathrm{UO}^{2+}{ }_{2}+\mathrm{Fe}^{2+}$, whereas the direct action involves the oxidation of $\mathrm{UO}_{2} \rightarrow \mathrm{UO}^{2+}{ }_{2}$ without using the $\mathrm{Fe}^{2+} / \mathrm{Fe}^{3+}$ complex as the chemical electron carrier.

Heterotrophic microbial activity. Dissolution of metals by heterotrophic microorganisms is due to production of organic acid metabolites, as well as lowering of the $\mathrm{pH}$ of the medium from the metabolism of organic compounds. In many cases, a combined effect is important. For example, when organisms secrete organic acids which may have a dual effect in increasing uranium dissolution by lowering $\mathrm{pH}$, and by complexation. Microbially produced dicarboxylic acids, ketogluconic acid, polyhydroxy acids, and phenolic compounds, such as protocate- 
chuic acid, and salicylic acid are effective chelating agents and are known to accelerate their movement in soils. A wide variety of heterotrophic microorganisms, such as Bacillus sp., B. luteus, B. subtilis, B. cereus, B. pumilis, Pseudomonas striata, P. viscosa, P. perolens, P. choloroaphis, Achromobacter xerosis, A. stoloniferum, and A. healii may be involved in solubilizing uranium from granitic rock where uranium is generally present as an oxide (Bhurat et al., 1973). Such solubilization is due to the production of organic-acid metabolites, such as oxalic, isocitric, citric, succinic, hydrobenzoic, and coumaric acids via their carboxylic and phenolic groups (Berthelin and Munier-Lamy, 1983; Bloomfield and Kelso, 1973; Bloomfield and Pruden, 1975; Bloomfield et al., 1971; and Bolter et al., 1975). When microorganisms are grown in an iron-deficient medium, they elaborate specific iron chelators, such as siderophores. Iron-sequestering agents could play an important role in the complexation of radionuclides and so increase their solubility. Pseudomonas aeruginosa CSU, grown in the presence of uranium or thorium, elaborated several metabolic products which complexed both elements (Premuzic et al., 1985, 1986).

\section{Immobilization of Uranium}

The immobilization of uranium is brought about by bioaccumulation, bioreduction and bioprecipitation reactions. Uranium is reduced by a wide variety of facultative and strict anaerobic bacteria under anaerobic conditions in the presence of suitable electron donor. Microbially mediated U reductions play an important role in the biogeochemical cycles of $U$. Consequently, the potential exists for the use of anaerobic bacteria to concentrate, contain and stabilize uranium in contaminated groundwaters and in waste with concurrent reduction in waste volume. However, the long-term stability of bacterially reduced uranium in the natural environment is not known.

Biosorption and bioaccumulation of uranium. Biosorption and bioaccumulation of uranium has been observed in a wide range of microorganism (Sakaguchi, 1996; Strandberg et al 1981). It is still one of the intensely investigated areas of research because of the potential use of biomass to remove uranium from waste streams. Uranium forms complexes with the carboxylate, phosphate, amino, and hydroxyl functional groups present on the cell surface; and intracellularly, by binding to anionic sites or precipitating as dense deposits. Nuclear magnetic resonance spectroscopy (NMR), time resolved laser fluorescence spectroscopy (TRLFS), and extended X-ray fluorescence spectroscopy (EXAFS) have been used to determine the functional groups involved in the complexation of $\mathrm{U}$ with bacteria.

Extracellular and intracellular association of $U$ with bacteria was observed but the extent of its accumulation differs greatly with the species of bacteria. Extracellular association of uranium with bacterial cell surfaces is primarily due to physical- and chemical- interactions involving adsorption, ion exchange, and complexation and does not depend on metabolism. Bacterial cell walls, exopolymers, 
proteins, and lipids contain functional groups, which are able to bind uranium. In Halomonas sp. U accumulated as electron-dense intracellular granules and was also bound to the cell surface (Figure 1). EXAFS analysis of the association of $U$ with halophilic and non-halophilic bacterial cells showed that it was associated predominantly with phosphate as uranyl hydrogen phosphate and additional forms of phosphate such as hydroxophosphato or polyphosphate complexes as well as other ligands such as carboxyl species (Francis et al., 2004). These results demonstrate that phosphate, including the polyphosphates, bind significant amounts of uranium in bacteria.

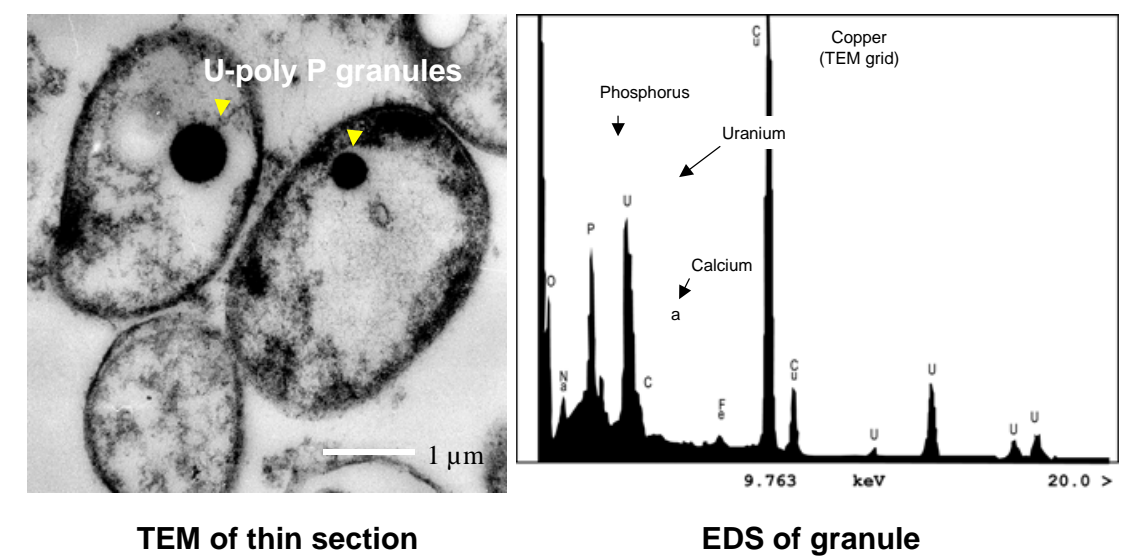

Figure 1. Intra- and extra- cellular accumulation of Uranium by Halomonas sp. After exposure to U, EDS shows $\mathrm{U}$ and $\mathrm{P}$ as the major constituents of the intracellular granules (Francis et al., 2004).

Intracellular accumulation involves transporting the metal across the cell membrane, which depends on the cell's metabolism. The intracellular transport of the U into the cell involves an as-yet unidentified transport system. Uranium transport across bacterial cell membranes may be mediated by the mechanism used to convey metabolically essential ions; however, additional studies are needed to clarify the exact mechanism involved.

Polyphosphates are widely distributed throughout the bacterial cell. Numerous and varied biological functions are performed by polyphosphate including phosphate storage in the cell, a reservoir of energy for cellular functions, a chelator of metals (e.g., $\mathrm{Mn}^{2+}$ and $\mathrm{Ca}^{2+}$ ), a $\mathrm{pH}$ buffer, a capsule for bacteria, and in physiological adjustments to growth, development, stress, and deprivation. In particular, the polyphosphates play a vital role in the dynamics of metabolic adjustments of cells to stationary phase and their survival in response to a variety of nutritional limitations and environmental stresses. The amount of polyphosphate that is stored by cells varies between bacterial species, and is determined in part by the rate at which it can be degraded for example, in response to the presence of metals, and the amount of inorganic phosphate secreted into the medium. In as much as all of uranium exposure studies reported were conducted with cells in the stationary 
phase, the cells are responding to heavy metal stress by releasing phosphate from the mineralization of cellular polyphosphate.

Bioreduction of uranium. A wide variety of facultative and strict anaerobic bacteria reduced $\mathrm{U}(\mathrm{VI})$ added as uranyl-nitrate or uranyl carbonate to $\mathrm{U}(\mathrm{IV})$ under anaerobic conditions (Wall and Krumholz, 2006). These include axenic cultures of iron-reducing, fermentative, and sulfate-reducing bacteria. Mixed cultures of bacteria in uranium contaminated ground waters and in wastes also reduced uranium. However, the stability of bioreduced uranium is a major concern because they can be readily reoxidized to the soluble U(VI)from. Metals associated with or coprecipitated with iron and manganese oxides and hydroxides can be remobilized due to reduction of host metal $\mathrm{Fe}^{3+}$ and $\mathrm{Mn}^{4+}$ (hydro)oxides either chemically or enzymatically (Stone and Morgan, 1987; Francis and Dodge, 1990) under anaerobic conditions.

\section{Biotransformation of uranium complexed with organic ligands}

Naturally occurring soluble organic complexing agents present at the uraniumcontaminated sites may not only affect the mobility of uranium but also affect the microbial transformation and reductive precipitation of uranium. Biotransformation of the complexed uranium should result in its precipitation and retard migration. There is a paucity of information on the mechanisms of microbial transformations of uranium complexed with naturally occurring low molecular weight soluble organic ligands.

We investigated the mechanisms of complexation and biotransformation of uranium with organic ligands ketogluconic, oxalic, malic, citric, protocatechuic, salicylic, phthalic, and fulvic acids and catechol. Potentiometric titration of uranium with the organic ligands confirmed complex formation and extended X-ray absorption fine structure (EXAFS) analysis and electrospray ionization-mass spectrometry (ESI-MS) showed that ketogluconic acid formed a mononuclear complex with uranium involving the carboxylate group, while malic acid, citric acid, and catechol formed binuclear complexes. Phthalic acid formed a bidentate complex involving the two carboxylate groups, while catechol bonded to uranium through the two hydroxyl groups. The hydroxycarboxylic acids were bound in a tridentate fashion to uranium through two carboxylates and the hydroxyl group.

Studies with anaerobic bacteria Clostridium sp. (ATCC 53464) and C. sphenoides (ATCC 53464) showed U(VI) complexed with organic ligands was reduced to $\mathrm{U}(\mathrm{IV})$ under anaerobic conditions with little precipitation of uranium. The reduction of $\mathrm{U}(\mathrm{VI})$-citrate to $\mathrm{U}(\mathrm{IV})$-citrate occurred only when supplied with an electron donor glucose or citrate. The bacteria did not metabolize the citrate complexed to the uranium. XANES analysis showed that the reduced form of uranium was present in solution while EXAFS analysis showed that the U(IV) was bonded to citric acid as a mononuclear biligand complex [U(IV)-cit ${ }_{2}$ (Francis and Dodge, manuscript submitted). Also the sulfate-reducing bacteria Desulfovibrio desulfuricans and the facultative iron-reducing bacteria Shewanella halotolerans 
reduced $\mathrm{U}(\mathrm{VI})$ complexed with oxalate or citrate to $\mathrm{U}(\mathrm{IV})$ under anaerobic conditions with little precipitation of uranium (Ganesh et al., 1997). These results show that the complexed uranyl ion is readily accessible as an electron acceptor despite the inability of the bacterium to metabolize the organic ligand. These results also suggest that reduced uranium, when complexed with an organic ligand, can remain in solution; this finding is contrary to the conventional belief that reduced uranium will precipitate from solution. The persistence of reduced uranium complexed with chelating agents in subsurface environments is a major concern because of the potential for increasing the transport of the radionuclide.

\section{Biotransformation of uranium in wastes and in sediment}

We investigated uranium-contaminated sediment and sludge samples from the West End Treatment Facility, at the U.S. Department of Energy, Oak Ridge Y-12 Plant, Oak Ridge, TN. The sludge was generated from a uranium-process waste stream after biodenitrification of nitric-acid uranium waste water, and the sediment was from a contaminated pond (New Hope Pond) which received

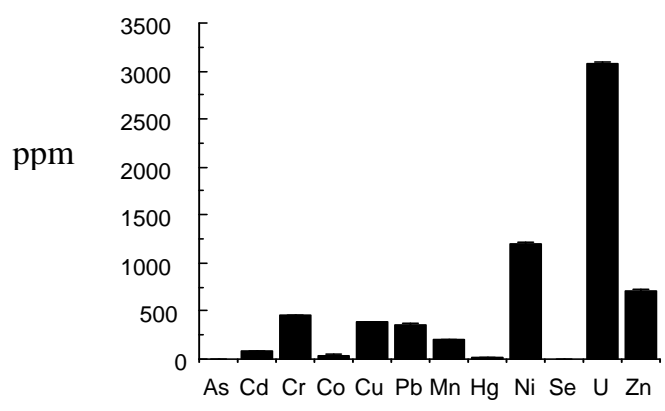

Figure 2. Analyses of metals in sludge uranium-process waste water. Several million gallons of the sludge is in storage awaiting disposal. Both sediment and sludge samples contained varying levels of major elements, Al, Ca, $\mathrm{Fe}, \mathrm{Mg}, \mathrm{K}$, and $\mathrm{Na}$, and toxic metals As, Cd, $\mathrm{Cr}, \mathrm{Co}, \mathrm{Cu}, \mathrm{Pb}$, $\mathrm{Mn}, \mathrm{Hg}, \mathrm{Ni}, \mathrm{U}$, and Zn (Figure 2). The concentrations of uranium in sediment and sludge samples were 920 and $3100 \mathrm{ppm}$, respectively. In addition to those elements reported above, analysis of the sediment sample by X-ray fluorescence showed the presence of titanium, gallium, bromine, strontium, rubidium, yttrium, and zirconium. The sludge was low in organic carbon and nitrogen but high in ash and sulfate; the latter resulted from adding sulfuric acid and ferric sulfate during the waste treatment process. Chemical analysis of the sludge supernate showed that the $\mathrm{pH}$ was alkaline, it was high in dissolved inorganic carbon (DIC) and sulfate, and low in nitrate; the $\mathrm{pH}$ of the sediment supernate was near neutral and contained high
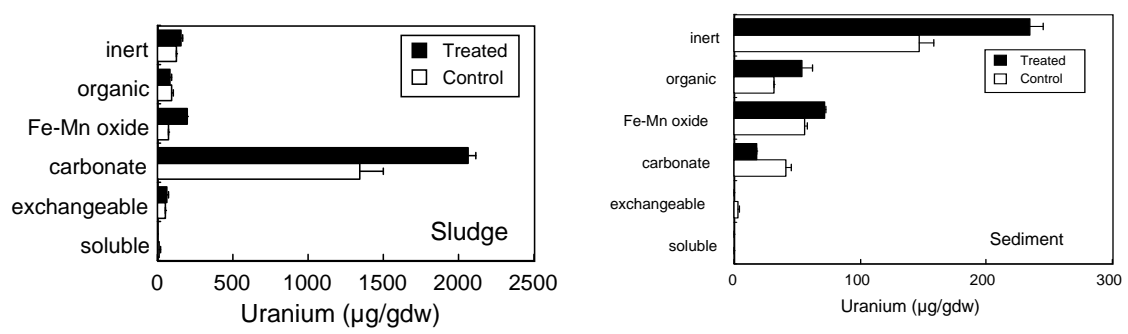

Figure 3. Mineralogical association of $U$ in sludge and sediment before and after microbial action 
dissolved organic carbon (DOC), and low levels of the other constituents tested.

The mineralogical association of cadmium, chromium, copper, manganese, nickel, lead, uranium, and zinc in the sludge and sediment was determined by a selective extraction procedure. Figure 3 shows these associations of uranium in the sludge and sediment before and after microbial action. A comparison of the total uranium obtained by digestion of the entire sample with the sum of the selective extractions showed good agreement within $\pm 10 \%$ ( \pm 1 SEM).

The sediment and sludge samples amended with glucose showed an increase in total gas, $\mathrm{CO}_{2}, \mathrm{H}_{2}, \mathrm{CH}_{4}$, and organic acids; $\mathrm{pH}$ was lowered by about 2.5 units. This change was due to the production of organic acid metabolites from glucose fermentation. The organic acids were acetic, butyric, propionic, formic, pyruvic, lactic, isobutyric, valeric, and isocaproic acids. A significant amount of gas was produced due to glucose fermentation by anaerobic bacteria, as well as from the dissolution of $\mathrm{CaCO}_{3}$ in the sludge by the organic acids. A decrease in sulfate concentration was observed only in amended samples.

This treatment process removed a large fraction of soluble non-toxic metals such as $\mathrm{Ca}, \mathrm{K}, \mathrm{Mg}, \mathrm{Mn}^{2+}, \mathrm{Na}$, and $\mathrm{Fe}^{2+}$, and enriched and stabilized $\mathrm{Cd}, \mathrm{Cr}, \mathrm{Cu}$,
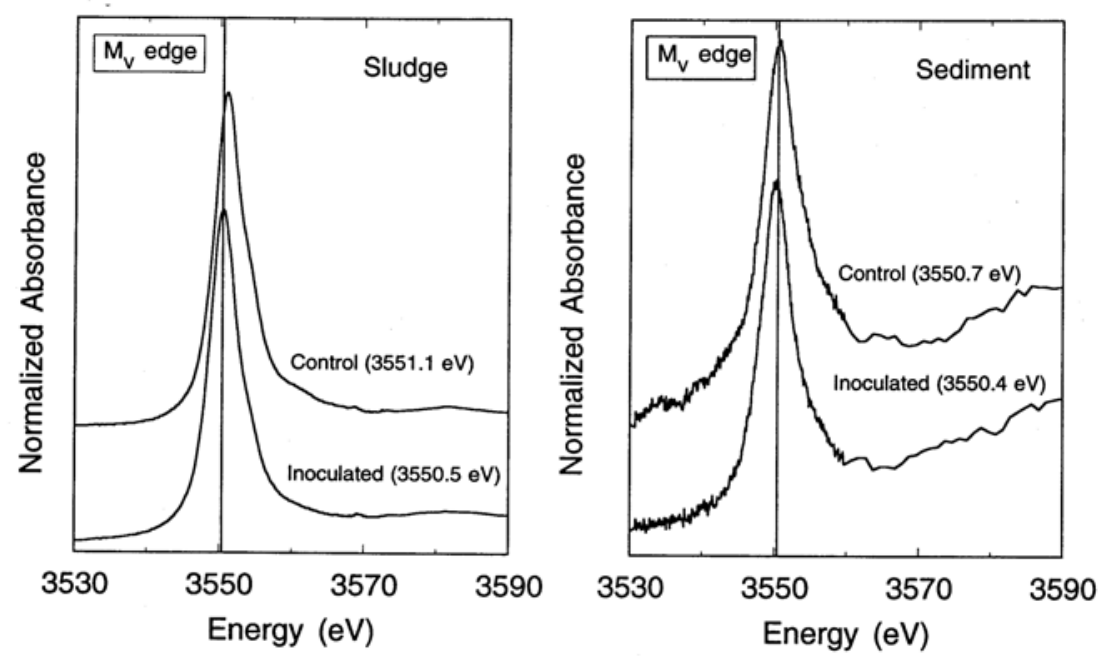

Figure 4. Comparison of XANES spectra of sludge and sediment before and after microbial treatment show reduction of $\mathrm{U}(\mathrm{VI})$ to $\mathrm{U}(\mathrm{IV})$.

$\mathrm{Ni}, \mathrm{Pb}, \mathrm{U}$, and $\mathrm{Zn}$ with the remaining solid phase due to direct and indirect actions of the bacteria (Francis, et al. 1991). Analysis of the mineralogical association of the metals in the wastes after microbiological action showed that many of the metals were redistributed with stable mineral phases, such as organic and silicate fractions (Figures 3). Metals associated with the exchangeable, carbonate, and iron oxide fractions were solubilized by indirect action due to the production of organic 
acid metabolites, whereas dissolution of iron oxides and metals coprecipitated with iron oxides was due to direct enzymatic reduction of iron. Uranyl ion associated with the exchangeable, carbonate, and iron-oxide fractions was released into solution by direct and indirect actions of the bacteria, and subsequently, was reduced enzymatically to insoluble U(IV). X-ray absorption near edge spectroscopic (XANES) analysis of uranium in the untreated (control) and treated sludge and sediment samples showed partial reduction of $\mathrm{U}(\mathrm{VI}) \rightarrow \mathrm{U}(\mathrm{IV})$ in the sludge and complete reduction in the sediment (Figure 4). Figure 5 illustrates the mechanisms of anaerobic microbial transformations of uranium in mixed wastes. Uranium was predominantly associated with the carbonate fraction and to a lesser extent with the oxide, organic, and inert fractions; after microbial activity its concentration increased for all three fractions.

Substantial amounts of calcium, iron, potassium, magnesium, manganese, and sodium were solubilized from the waste, reducing the mass $\sim 15-20 \%$ in these batch studies. Further reductions in waste volume can be achieved by optimizing the process using a continuous treatment system to solubilize and remove the bulk of non-toxic waste components, particularly calcium, potassium, iron, magnesium,

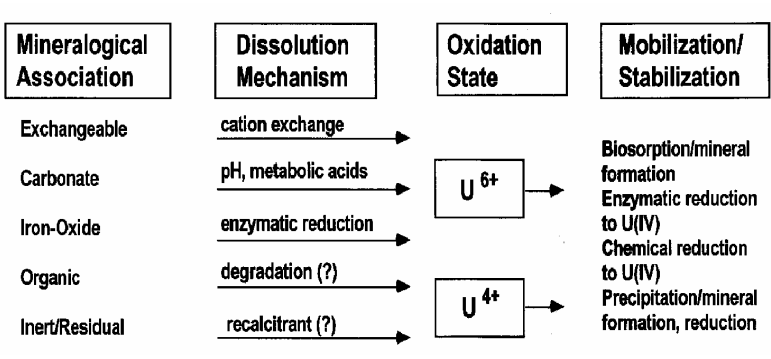

Figure 5. Proposed mechanisms of microbial ransformation of uranium in mixed waste. and manganese. This biotreatment can be applied to mixed wastes containing radioactive elements and toxic metals generated from defense, energy, and industrial operations wastes to chemically convert the radionuclides and metals to more stable forms. Reducing the mass of the wastes means that more material can be stored or disposed of, can be handled easier, and can be transported. Converting the radionuclides and toxic metals to more stable forms allows the material to be processed chemically, for disposal in shallow or deep geological formations.

Fundamental understanding of the mechanisms of interactions of microorganisms with uranium associated with naturally occurring organic and inorganic ligands and colloids at the molecular level under various microbial process conditions will aid in the development of appropriate remediation strategies and longterm stewardship of contaminated sites.

\section{Acknowledgement}

This research was supported by the Environmental Remediation Sciences Program, Office of Biological and Environmental Research (OBER), Office of Science, U. S. Department of Energy, under contract No. DE-AC02-98CH10886. 


\section{References}

Katz, J.J.; G.T. Seaborg; L.R. Morss. The Chemistry of the Actinide Elements, $2^{\text {nd }}$ Ed., Vol. 1, Chapman and Hall, NY, 1986.

Metzler, D.R. 2004. Uranium mining: Environmental impact. Encyclopedia of Energy, 6:299-315

Bostick, B. C.; M. O. Barnett; P. Jardine; S. Fendorf; S. Brooks. 2002. Speciation of uranium in packed soil columns. Soil Sci. Soc. Am. J. 66:99-108.

Berthelin, J. and C. Munier-Lamy. 1983. Microbial mobilization and preconcentration of uranium from various rock materials by fungi. In R. Hallberg, (ed.) Environmental Biogeochemistry. Ecol. Bull., Stockholm. 35:395-401.

Bhurat, M. C., K. K. Dwivedy, K. M. V. Jayaram, and K. K. Dar. 1973. Some results of microbial leaching of uranium ore samples from Narwepahar, Bhatin and Kerudungri, Singhbhum District, Bihar. NML Technical J. 15:47-51.

Bloomfield, C. and W. I. Kelso. 1973. The mobilization and fixation of molybdenum, vanadium, and uranium by decomposing plant matter. J. Soil Sci. 24:368-379.

Mathur, A. K. and K. K. Dwivedy. 1988. Biogenic approach to the treatment of uranium mill effluents. Uranium 4:385-394.

Mohagheghi, A., D. M. Updegraff, and M. B. Goldhaber. 1985. The role of sulfatereducing bacteria in the deposition of sedimentary uranium ores. Geomicrobiol. J. 4:153-173.

Munier-Lamy, C. and J. Berthelin. 1987. Formation of polyelectrolyte complexes with the major elements $\mathrm{Fe}, \mathrm{Al}$, and trace elements $\mathrm{U}$, and $\mathrm{Cu}$ during heterotrophic microbial leaching of rocks. Geomicrobiol J. 5:119-147.

Berthelin, J. and C. Munier-Lamy. 1983. Microbial mobilization and preconcentration of uranium from various rock materials by fungi. In R. Hallberg, (ed.) Environmental Biogeochemistry. Ecol. Bull. Stockholm 35: 395-401.

Bloomfield, C. and G. Pruden. 1975. The effects of aerobic and anaerobic incubation on the extractabilities of heavy metals in digested sewage sludge. Environ. Pollut. 8: 217-232.

Brainard, J. R., B. A. Strietelmeier, P. H. Smith, P. J. Langston-Unkefer, M. E. Barr, and. R. R. Ryan. 1992. Actinide binding and solubilization by microbial siderophores. Radiochim Acta, 58-59: 357-363.

Francis, A. J. 1985. Microbial transformations of low-level radioactive wastes in subsoils. In Soil Reclamation Processes: Microbiological Analyses and Applications, R.L. Tate and D. Klein, (Eds.), pp. 279-331, Marcel Dekker, New York, 1985.

Francis, A.J. 1990. Microbial dissolution and stabilization of toxic metals and radionuclides in mixed wastes. Experientia 46: 840-851.

Francis, A.J. 1994. Microbial transformations of radioactive wastes and environmental restoration through bioremediation. J. Alloys and Compounds 213/214: 226-231.

Francis, A. J. and C. J. Dodge. 1990. Anaerobic microbial remobilization of toxic metals coprecipitated with iron oxide. Environ. Sci. Technol. 24: 373-378.

Francis, A.J., C.J. Dodge, F. Lu, G. Halada, and C.R. Clayton. 1994. XPS and XANES studies of uranium reduction by Clostridium sp. Environ. Sci. Technol. 28: 636-639.

Francis A.J, J.B Gillow, C.J Dodge, R Harris, T.J Beveridge, and H.W Papenguth. 2004. Association of uranium with halophilic and nonhalophilic bacteria and archaea. Radiochim. Acta 92: 481-488. 
Ganesh R., K.G. Robinson, G.R. Reed, and G. S. Saylor. 1997. Reduction of hexavlaent uranium from organic complexes by sulfate- and iron-reducing bacteria. Appl. Environ. Microbiol. 63: 4385-4391.

Sakaguchi, T. 1996. Bioaccumulation of Uranium. Kyushu University Press, Hukuoka, Japan.

Stone, A.T. and J.J. Morgan. 1987. Reductive dissolution of metal oxides, in: Aquatic surface Chemistry: Chemical Processes at the Particle Water Interface, pp 221-254. Ed. W. Stumm. John Wiley and Sons, Inc., New York.

Strandberg, G.W., S.E. Shumate II, and J. R. Parrot Jr. 1981. Microbial cells as biosorbents for heavy metals: accumulation of uranium by Saccharomyces cerevisiae and Pseudomonas aeruginosa. Appl. Environ. Microbiol.41: 237-245. 